\title{
Epidemiology and Cutaneous Manifestations of Psoriasis in Saudi Arabia: A Narrative Review
}

\author{
Faisal Alzeer', Hadil AlOtair $\mathbb{D}^{2}$, Abdullah Aleisa ${ }^{3}$ \\ 'College of Medicine, King Saud University, Riyadh, Saudi Arabia; ${ }^{2}$ Department of Medicine, King Saud University Medical City, Riyadh, Saudi Arabia; \\ ${ }^{3}$ Memorial Sloan Kettering Cancer Center, New York, NY, USA \\ Correspondence: Faisal Alzeer, College of Medicine, King Saud University, P.O. Box I832I, Riyadh, II4I5, Saudi Arabia, Tel +9665044I0525, \\ Email faisalalzeerfz@gmail.com
}

\begin{abstract}
Background: Psoriasis is an inflammatory immune-mediated illness with an unknown cause. It is a painful, disfiguring, and disabling condition without a complete cure and has enormous negative effects on patients' quality of life. Ethnicity, genetics, and environmental variables all have a role in determining the disease's prevalence. Currently, the large-scale epidemiological studies on cutaneous manifestations of psoriasis in Saudi Arabia are limited.

Aim: To evaluate the prevalence of different forms of psoriasis and cutaneous manifestations, pattern, and associated clinical presentation of psoriasis in the Kingdom of Saudi Arabia (KSA).

Methodology: A thorough search of studies on cutaneous manifestations of psoriasis in KSA was conducted from July first 2021 to September 302021 using the key phrases "psoriasis," "cutaneous manifestations of psoriasis in KSA," "psoriasis clinical presentation in Saudi Arabia," and "psoriasis skin lesions in Saudi Arabia" at four medical search stations PubMed, Scopus, Google, and Research Gate.

Results: Psoriasis was found to be present in up to $5.33 \%$ of the population. More men than women were affected and the age of onset was under 30 years. It was more prevalent in the northern region of KSA. A family history was confirmed in many cases. Plaque psoriasis was the most prevalent kind of psoriasis, followed by guttate psoriasis. Other types of psoriasis, such as pustular psoriasis, erythrodermic psoriasis, follicular psoriasis, inverse psoriasis, and congenital psoriasis, were also found in Saudi patients. There was no evidence of life-threatening psoriasis among Saudis.

Conclusion: The major findings of this narrative review revealed plaque-type psoriasis was the most frequent among Saudis followed by guttate psoriasis. Further epidemiological research is needed to better understand the type of cutaneous psoriasis, its impact on the quality of life, and the current therapeutic options which would help advance the national health policy.
\end{abstract}

Keywords: psoriasis, cutaneous manifestations, prevalence, Saudi Arabia

\section{Introduction}

Psoriasis is a complex and multifactorial chronic inflammatory autoimmune skin disease associated with systemic manifestations. The interaction between genetic and environmental factors comprises an interplay in the pathogenesis of psoriasis. ${ }^{1}$ It can occur at any age, although it is most common between the ages of 15 and $30{ }^{1,2}$ Even though psoriasis is not contagious, the affected individuals experience significant social and psychological problems as a result of its disfiguring and debilitating effects, including loss of productivity and, worst of all, social rejection and a negative impact on their quality of life (QoL). Furthermore, psoriasis is considered a major health concern that requires a complete cure, and a well-monitored treatment can reduce its morbidity and improve quality of life.

The global prevalence is estimated to be around $2 \%$; however, this differs from country to country. ${ }^{3}$ The prevalence of psoriasis in different nations has been observed to range from $0.09 \%$ to $11.4 \%{ }^{4}$ Psoriasis is prevalent in irregular intensity among different populations and ethnic groups around the world. Adult prevalence estimates range from $0.51 \%$ to $11.43 \%$, while children's prevalence estimates range from $0 \%$ to $1.37 \%{ }^{5}$ Psoriasis is considered an immune-mediated chronic illness with the involvement of crucial genetic components; however, still the identification of its causative 
immunogen has not been discovered. ${ }^{6,7}$ The condition is thought to start when an unknown antigen activates $\mathrm{T}$ cells, causing them to secrete a variety of cytokines, which are then released by activated $\mathrm{T}$ cells, inflammatory cells, and keratinocytes. Thus, psoriasis can be attributed to a deficiency in keratinocyte proliferation and differentiation, as well as inflammatory cell infiltration, including T-lymphocytes, macrophages, and neutrophils. ${ }^{8}$ The hyper-proliferation of the keratinocyte causes the typical psoriasis lesion; therefore, psoriasis is characterized by a high rate of epidermal turnover. ${ }^{9}$ Psoriasis shows a genetic predisposition, but environmental variables also play a role in clinical manifestations of the disease. Therefore, ethnicity, genetics, and environmental variables all have a role in determining the disease's prevalence. In comparison to other ethnic groups, higher prevalence rates have been found in those living in higher latitudes and white people. ${ }^{6,7}$

In this narrative review, we provide outcome of a literature search on cutaneous manifestation, prevalence, and clinical characteristic of psoriasis with a focus on Saudi Arabia.

\section{Literature Survey}

A thorough search on cutaneous manifestations of psoriasis in the KSA was conducted from July 01, 2021 to September 30, 2021 using the key phrases "psoriasis," "cutaneous manifestations of psoriasis in KSA," "psoriasis clinical presentation in Saudi Arabia," and "psoriasis skin lesions in Saudi Arabia" at four medical search stations PubMed, Scopus, Google, and Research Gate. Only English-language articles were reviewed.

\section{Results}

\section{Psoriasis Prevalence in Saudi Arabia}

The prevalence of psoriasis in the Kingdom of Saudi Arabia (KSA) varies from province to province with time, and there has been a continuous increasing trend in recent years. The highest reported to be $5.33 \%$ in Al-jouf (northern region). ${ }^{10}$ In the last decade, various studies have demonstrated the pattern of skin-related conditions in several parts of Saudi Arabia, including Asir, Riyadh, Madinah, Jeddah, Al-Khobar, Al-Baha, Qassim, Hail, Abha, Najran and Qunfudah, spanning the eastern and western province and southwestern Saudi Arabia. ${ }^{11-16}$ However, large-scale epidemiological studies on cutaneous manifestations of psoriasis in Saudi Arabia remain rare.

In eastern and southwestern Saudi Arabia, psoriasis prevalence is estimated to be $1.5 \%$ and $3.4 \% .{ }^{13,14}$ However, a study by Al-Saeed et al demonstrated a much lower prevalence of psoriasis $(0.3 \%)$ in women. ${ }^{15}$ Later, Al-Hoqail et al reported a higher prevalence of psoriasis among women (3.2\%) and men (5.5\%). ${ }^{16}$ Following this, Alshamrani et al reported a total of $5.1 \%$ prevalence of psoriasis among Saudis. ${ }^{17}$

\section{Clinical Spectrum and Types of Psoriasis}

The presentation of psoriasis can occur in different forms; from red scaling raised plaques on the elbows, knees, or scalp to superficial pustules dispersed on the palms or soles, or, in rare cases, wide-spread pustules all over the body. The plaque, guttate, small plaque, inverse, erythrodermic, and pustular forms of psoriasis are among the clinical spectrum's variants (Supplementary Table). Plaque-type psoriasis is the most prominent form of psoriasis and appears as elevated red plaques with well-defined borders that are covered with silvery scales. The extensor surface of elbows and knees, the scalp, and the lower back are the most common sites of appearance, but it can also affect other parts of the body, with varying lesion sizes and symmetrical distribution. ${ }^{18}$ A variety of factors influence the clinical severity of psoriasis. ${ }^{19}$ These include variations in presentation, type of psoriasis, the extent of skin involvement, and the location of skin lesions, such as the scalp, face, nails, palmoplantar surfaces, and intertriginous regions. Psoriasis can also develop in a variety of ways, including extracutaneous symptoms. ${ }^{3}$

\section{Types of Psoriasis Reported in Saudi Arabia}

Over two decades, several studies have reported the prevalence of different types of psoriasis in different regions of Saudi Arabia (Table 1) with enormous variability in the rate of psoriasis prevalence in both males and females; adults and children. In the Hail (northern region), Psoriasis was found to be the most common papulosquamous disorder, accounting for 
Table I Different Studies Showing Cutaneous Manifestations and Prevalence of Psoriasis Among Saudi Population

\begin{tabular}{|c|c|c|}
\hline Reference & Region & Findings \\
\hline $\begin{array}{l}\text { Agarwal PK } \\
1997^{10}\end{array}$ & Al-Jouf Region & $\begin{array}{l}\text { Psoriasis was found to the most common papulosquamous disorder, accounting for } 71.34 \% \text { and } 5.33 \% \text { of } \\
\text { all the skin diseases. }\end{array}$ \\
\hline $\begin{array}{l}\text { Bahamadan et al } \\
1995^{28}\end{array}$ & ASIR Region & Prevalence of psoriasis: $2.01 \%$. \\
\hline $\begin{array}{l}\text { Raddadi et al } \\
1997-98^{29}\end{array}$ & Jeddah & Prevalence: $3.01 \%$; $1.51 \%$ had psoriasis. \\
\hline $\begin{array}{l}\text { Parthasaradhi et al } \\
1998^{20}\end{array}$ & Hail & $\begin{array}{l}\text { Psoriasis was the most common papulosquamous Disorder, accounting for } 57.35 \% \text { of the cases. The } \\
\text { prevalence of papulosquamous disorders was higher in Al-Jouf }(7.47 \%) \text { and Hail }(6.18 \%) \text { when compared } \\
\text { to Asir }(4.82 \%) \text {. }\end{array}$ \\
\hline Fatani et al $2002^{21}$ & Al-Khobar & $\begin{array}{l}\text { Occurrence of psoriasis: 5.3\%; M/F ratio of I.4:I; mean age of onset: Males } 26.9 \text { years and Females } 22.3 \\
\text { years; family history: } 8.4 \% \text {; sites: lower extremity }(44.9 \%) \text {, scalp }(4 I .8 \%) \text {, nail }(26.6 \%) \text {, and palmoplantar } \\
\text { (I2.6\%); most common: plaque psoriasis }(87.1 \%) \text {, erythrodermic }(4.2 \%) \text {, pustular }(3 \%) \text {, guttate (I.9\%), } \\
\text { flexural, }(2.3 \%) \text {, and follicular }(0.4 \%) \text {. }\end{array}$ \\
\hline $\begin{array}{l}\text { Shellehand Al- } \\
\text { Hatiti } 2004^{13}\end{array}$ & Najran & $\begin{array}{l}\text { Prevalence: } 1.5 \mathrm{I} \% \text {; Najran was lower than others in psoriasis. } 37 \% \text { had dermatitis or eczema, } 12.75 \% \text { had } \\
\text { acne, } 7 \% \text { had vitiligo, and } 5.9 \% \text { had viral infections. }\end{array}$ \\
\hline $\begin{array}{l}\text { Al-Maghrabi et al } \\
2004^{30}\end{array}$ & AlBaha & $\begin{array}{l}\text { Mean age: } 62.2 \text { years; male predominance; } 41 \% \text { of patients had basal cell carcinoma, } 29 \% \text { had squamous } \\
\text { cell carcinoma, and } 18 \% \text { had Kaposi's sarcoma; malignant melanomas accounted for } 4.1 \% \text { of all cases. }\end{array}$ \\
\hline Al Akloby $2005^{14}$ & $\begin{array}{l}\text { Eastern } \\
\text { province }\end{array}$ & $\begin{array}{l}\text { Dermatitis/eczema was the most common dermatosis (19.6\%), with atopic dermatitis accounting for } \\
35.9 \% \text { of all eczemas. Dermatophytoses accounted for } 6.3 \% \text { of all patients with fungal infections }(9.6 \%) \\
\text { and papulosquamous diseases } 6.4 \% \text {, of which } 3.4 \% \text { had psoriasis. }\end{array}$ \\
\hline $\begin{array}{l}\text { Al-Saeed et al } \\
2006^{15}\end{array}$ & Al-Khobar & $\begin{array}{l}\text { Pigmentary disease was the most prevalent skin illness }(91.6 \%) \text {, followed by dermatitis/eczema and } \\
\text { related conditions }(26.7 \%) \text { and disorders of skin appendages }(25.3 \%) \text {. Melanocytic nevi }(\mathrm{MN})(68 \%) \text { were } \\
\text { the most common skin disorders, followed by post-inflammatory pigmentation }(56.6 \%) \text {, scars }(26.8 \%) \text {, } \\
\text { acne }(22.5 \%) \text {, dandruff }(18.1 \%) \text {, pediculosis capitis }(5.2 \%) \text {, and eczema }(3.1 \%) \text {. }\end{array}$ \\
\hline $\begin{array}{l}\text { Al-Zoman et al } \\
2008^{31}\end{array}$ & Central Region & Dermatitis/Eczemas: $21.29 \%$; acne: $11.88 \%$; erythematosquamous: $4.61 \%$. \\
\hline Amin et al $2011^{32}$ & AlHessa & Prevalence of psoriasis: $0.2 \%$ in male children bellow 13 years. \\
\hline $\begin{array}{l}\text { Bhutto et al } \\
20 I^{22}\end{array}$ & Riyadh & $\begin{array}{l}\text { Psoriasis: } 33.3 \% \text { had generalized (plaque type), } 22.2 \% \text { had guttate, } 1 \mathrm{I} . \mathrm{I} \% \text { had mixed guttate; plaque type: } \\
16.7 \% \text { had localized lesions on elbows and knees, } 1 \mathrm{I} .1 \% \text { had on hands and feet, } 2.8 \% \text { had on scalp, and } \\
2.8 \% \text { had erythematous lesions all over the body since birth (congenital psoriasis); male/female ratio was } \\
\text { I:I.4. Family history was positive in } 27.8 \% \text {. }\end{array}$ \\
\hline $\begin{array}{l}\text { Alsuwaidan et al } \\
2011^{33}\end{array}$ & Riyadh & $\begin{array}{l}66.6 \% \text { had generalized plaque type psoriasis, } 22.2 \% \text { had guttate, } 11.1 \% \text { had mixed plaque type, } 16.67 \% \text { had } \\
\text { localized plaque type (on elbows and knees), } 11.11 \% \text { had palmoplantar psoriasis, and } 2.77 \% \text { had scalp } \\
\text { psoriasis. }\end{array}$ \\
\hline $\begin{array}{l}\text { Alhumidi et al } \\
2013^{23}\end{array}$ & KSA & $\begin{array}{l}69 \% \text { of patients presented with plaques, } 8 \% \text { guttate psoriasis, } 3 \% \text { with patches, } 5 \% \text { with pustular psoriasis, } \\
3 \% \text { linear psoriasis, } 2 \% \text { were erythrodermic psoriasis, and } 2 \% \text { in annular fashion; site of involvement: } \\
\text { lower extremity }(42 \%) \text {, upper extremity }(27 \%) \text {, back }(22 \%) \text {, abdomen }(18 \%) \text {, palm and sole }(20 \%) \text {, genital } \\
\text { area }(9 \%) \text {, axilla }(8 \%) \text {, scalp }(8 \%) \text {, face }(5 \%) \text {, buttock }(4 \%) \text {, sub mammary area }(5 \%) \text {, and umbilicus }(3 \%) \text {. }\end{array}$ \\
\hline $\begin{array}{l}\text { Al-Hoqail et al } \\
2013^{16}\end{array}$ & Majma & $\begin{array}{l}\text { Psoriasis: } 5.1 \% \text { overall, with } 10.4 \% 2 \mathrm{I}-30 \text { years of age. Eczema was the most prevalent diagnosis, } \\
\text { accounting for } 15.81 \% \text {, followed by acne at } 14.71 \% \text { and dermatitis at } 12.33 \% \text {, among noninfectious } \\
\text { dermatological diseases. The number of patients infected with eczema was considerably greater }(\mathrm{p}<0.05) \\
\text { in women }(18.6 \%) \text { than men }(12.6 \%) \text { in noninfectious dermatological diseases. }\end{array}$ \\
\hline Shajeri et al $2014^{24}$ & $\begin{array}{l}\text { Asir and Najran } \\
\text { regions }\end{array}$ & $\begin{array}{l}\text { Guttate psoriasis was most common, occurring in } 64 \% \text { of patients, followed by plaque psoriasis }(52 \%) \text {, } \\
\text { and inverse psoriasis }(4 \%) \text {. The most common clinical form was guttate psoriasis }(64 \%) \text { in children }<10 \\
\text { years. }\end{array}$ \\
\hline Al Fahaad $2015^{34}$ & Najran & $\begin{array}{l}\text { Vitiligo cases among the dermatology outpatient clinic attendees was } 1.98 \% \text {. Vitiligo patients were } \\
\text { predominantly males }(57.4 \%) \text {. The highest number }(48.5 \%) \text { of patients presented a localized type of } \\
\text { vitiligo, whereas } 22.8 \% \text { had acrofacial, } 20.8 \% \text { showed vulgaris, } 5 \% \text { presented universal, } 2 \% \text { had acral, and } \\
\text { I\% experienced a segmental type of vitiligo. }\end{array}$ \\
\hline
\end{tabular}


Table I (Continued).

\begin{tabular}{|c|c|c|}
\hline Reference & Region & Findings \\
\hline Fatani et al $2016^{35}$ & Makkah & $\begin{array}{l}\text { Male patients with psoriasis were presented in } 48.1 \% \text { whereas women in } 51.9 \% \text { women (sex ratio } 1: I . I \text { ). } \\
\text { In the majority of patients }(60.8 \%) \text {, onset occurred before the age of } 40 ; 27.3 \% \text { had a positive family } \\
\text { history; and } 73.2 \% \text { had concomitant comorbidities. }\end{array}$ \\
\hline Hasan et al $2017^{25}$ & Riyadh & $\begin{array}{l}\text { Plaque psoriasis was most common, occurring in } 24 \% \text {, The guttate type of psoriasis was found in } 2 \% \text {, } \\
\text { while the pustular type of psoriasis was found in } 5 \% \text { and psoriasis vulgaris } 30 \% \text {. }\end{array}$ \\
\hline $\begin{array}{l}\text { Al Shammrie et al } \\
2017^{11}\end{array}$ & Hail & $\begin{array}{l}\text { The prevalence of psoriasis was } 4 \% \text {; dermatitis, acne, vitiligo, alopecia, viral warts, and psoriasis were the } \\
\text { most common (top six) skin conditions in the Hail region. }\end{array}$ \\
\hline $\begin{array}{l}\text { Albahlool et al } \\
2017^{36}\end{array}$ & KSA & $\begin{array}{l}\text { Randomizedcontrolledtrial showed acne, eczema and psoriasis are the most common dermatological } \\
\text { disorders among the Saudi, while atopic dermatitis was mostly affecting children. Psoriasis arose as the } \\
\text { most recurrent papulosquamous condition. }\end{array}$ \\
\hline $\begin{array}{l}\text { Rahamathulla et al } \\
2019^{37}\end{array}$ & $\begin{array}{l}\text { Wadi Al } \\
\text { Dawasar }\end{array}$ & Cross-sectional study on children. The occurrence of psoriasis was $2.5 \%$. \\
\hline $\begin{array}{l}\text { Albarraq et al } \\
2019^{38}\end{array}$ & Jizan & This is a review on the prevalence and pharmacotherapeutic management of pediatric psoriasis. \\
\hline Elnady et al $2019^{39}$ & KSA & $\begin{array}{l}\text { The yearly psoriatic arthritis (PsA) incidence was } 4.3 \% \text { during a two-year follow-up of patients. Patients } \\
\text { with psoriasis who developed PsA had a greater rate of baseline enthesitis, higher power Doppler } \\
\text { ultrasound (PDUS) and grayscale ultrasound (GSUS) synovitis scores, and a higher baseline CRP level than } \\
\text { those who did not develop PsA. Subclinical enthesitis and synovitis were found in } 39.5 \% \text { of psoriasis } \\
\text { patients and } 0 \% \text { of controls. }\end{array}$ \\
\hline Almohideb $2020^{26}$ & Riyadh & $\begin{array}{l}\text { Meta-analysis of } 30,436 \text { patients with skin diseases from different regions of the KSA; the prevalence of } \\
\text { psoriasis among these patents was } 3.9 \% \text { more in males. }\end{array}$ \\
\hline $\begin{array}{l}\text { Almutairi et al } \\
2020^{40}\end{array}$ & Riyadh & $\begin{array}{l}78 \% \text { of the study participants were familiar with psoriasis. Most of the participants had heard about the } \\
\text { term 'psoriasis' from their family or friends. } 68 \% \text { of participants thought the disease was a big burden on } \\
\text { those who had it, } 41 \% \text { said there are effective medications for treating psoriasis, and } 12.2 \% \text { thought it was } \\
\text { contagious. Some individuals refused to shake hands, share their meals, swim in the same pool as, or be in } \\
\text { a relationship with psoriasis patients }(18.2 \%, 13 \%, 54.1 \% \text {, and } 32 \% \text { respectively). }\end{array}$ \\
\hline Alajmi et al $2021^{27}$ & Jeddah & $\begin{array}{l}\text { Out of } 128 \text { confirmed psoriasis cases, plaque psoriasiswas diagnosed in } 57.0 \% \text {, followed by those with } \\
\text { psoriatic arthritis at } 13.3 \% \text {. There were only a few cases of nail psoriasis ( } 0.8 \%) \text {, pustular psoriasis (I.6\%), } \\
\text { and inverse psoriasis }(1.6 \%) \text {. }\end{array}$ \\
\hline
\end{tabular}

$57.35 \% .{ }^{20}$ Further, age was identified as another crucial factor that has a predominant role in the clinical manifestation of psoriasis in different countries, including Saudi Arabia. Fatani et al reported the occurrence of psoriasis in King Fahd hospital, Al-Khobar (eastern region) at 5.3\% of the patients following up dermatology clinic whereby $53 \%$ of individuals develop the disease before they reached the age of 30 years, in which $8.4 \%$ of the them had a family history of psoriasis. ${ }^{21}$ This study also showed the involvement of lower extremities (44.9\%), scalp (41.8\%), nail (26.6\%), and palmoplantar $(12.6 \%)$ as the major involved sites in the body. The most frequent reported clinical form was plaque psoriasis $(87.1 \%)$, followed by erythrodermic psoriasis (4.2\%), pustular psoriasis (3\%), guttate psoriasis (1.9\%), flexural psoriasis (2.3\%), and follicular psoriasis $(0.4 \%)$. In $43 \%$ of cases, itching was identified as the most common symptom mentioned by patients. Later, Bhutto et al reported different types of childhood psoriasis. Among 36 children, 33\% had generalized plaque type of psoriasis while $22.2 \%$ had guttate psoriasis and $11.1 \%$ had mixed type of psoriasis. Family history was positive in $27.8 \%{ }^{22}$

Al-Saeed et al conducted a cross-sectional study in Al-Khobar (eastern region), on 2239 female school children randomly selected from 30 regular public and private primary and preparatory schools. ${ }^{15}$ They reported that the frequency of skin problems among female school children in Al-Khobar city was particularly high (98.6\%), and it was advised that a preventive health education programme on skin diseases be implemented for school children at various levels, as well as their families and teachers. Alhumidi et al reported the average age of onset of a patient with psoriasis is 31 years and that $69 \%$ of patients have plaque psoriasis in the KSA. ${ }^{23}$ Shajeri et al investigated the characteristics of psoriasis in children aged one to 10 years in the southern area of Saudi Arabia (Asir and Najran regions) and reported the guttate form of psoriasis as the most prevalent (64.0\%), followed by plaque psoriasis (52\%) and 
inverse psoriasis (4\%). ${ }^{24}$ Similarly, Hassan et al reported plaque psoriasis as the most prevalent $(24 \%)$ form of psoriasis in a tertiary hospital in Riyadh (central region). ${ }^{25}$

A recent systematic review and meta-analysis demonstrated the pattern of skin disorders in a total of 30,436 patients of different geographical locations of Saudi Arabia (Almohideb, 2020) and reported skin appendages (24.8\%) and dermatitis (24.0\%) as the most often reported skin disorders in Saudi Arabia. ${ }^{26}$ Skin infection accounted for 18.5\%, whereas papulosquamous disorders accounted for 5.3\%. Psoriasis accounted for 3.9\%, whereas lichen planus accounted for $1.8 \%$. Another, most recent cross-sectional study by Alajmi et al from Jeddah (western region) reported 33.6\% unidentified psoriasis. ${ }^{27}$ The majority of patients, however, were diagnosed with plaque psoriasis (57.0\%), followed by those with psoriatic arthritis (13.3\%). There were only a few cases of nail psoriasis $(0.8 \%)$, pustular psoriasis $(1.6 \%)$, and inverse psoriasis $(1.6 \%){ }^{27}$

Various local studies have also reported the prevalence of other types of psoriasis involving different sites among Saudis. (Table 2) These studies warrant further investigation for controlling psoriasis and psoriasis-related cutaneous manifestations in Saudi Arabia.

\section{Key Findings}

The above-mentioned studies revealed that psoriasis is relatively common in Saudi Arabia, with a prevalence of up to $5.33 \%$, and has risen somewhat over time. Male patients were more susceptible and predominant in the majority of studies in the kingdom. The age of psoriasis emergence in male patients was less than 30 years, whereas the illness appears later in female patients. Some studies suggest individuals with psoriasis had a familial history of the disease and that psoriasis prevalence was linked to genetic susceptibility. This study examined the cutaneous manifestations of psoriasis in Saudi Arabia in depth. The plaque form of psoriasis was shown to be the most frequent type of skin manifestation. Guttate psoriasis was the second most common kind of psoriasis. Other types of psoriasis, such as pustular psoriasis, erythrodermic psoriasis, follicular psoriasis, inverse psoriasis, congenital, and mixed psoriasis were also found in the KSA. The lower limbs were the most common location of psoriasis presentation among Saudi patients. The scalp was the second most common location, followed by the palmoplantar, elbow, and genitalia.

\section{Discussion}

Psoriasis is a critical public health problem since it has a significant impact on QoL and has financial ramifications. Even though psoriasis is not contagious, patients may face significant social stigmatization and psychological problems as a result of its disfiguring and debilitating effects, including loss of productivity and, worst of all, social rejection. Furthermore, psoriasis is considered a significant health condition that requires care because of related comorbidities, particularly cardiovascular complications. ${ }^{42}$ It is underdiagnosed and undertreated throughout the world. Many nations, including the KSA lack a high-quality health registry on psoriasis.

Large epidemiological research on cutaneous manifestations of psoriasis is infrequent in Saudi Arabia. Several studies have looked into the pattern of skin disorders in different parts of the kingdom. This review reveals that psoriasis is fairly common in Saudi Arabia, with a frequency range from 1.51\% in Najran (southern region) as high as 5.33\% in Al-jouf (northern region). ${ }^{10,13}$ This variation may be related to different methodological studies and heterogeneity of the data presented. These data also are higher than estimated reports by many countries. ${ }^{42}$ Thus, they need to be interpreted with caution. In addition, the prevalence of psoriasis has risen somewhat over time in keeping with international studies. ${ }^{43-45}$ This increase may be attributed to the interaction between the genetic and environmental factors as well as the availability of health care systems to provide psoriasis care. ${ }^{45}$ Further studies are needed to establish the proper rationale for the rise in psoriasis prevalence in Saudi Arabia. Male patients are more sensitive to psoriasis according to the current study, and there is a male predominance in both the frequency and severity of psoriasis among Saudis. However, there was no agreement about whether the prevalence of psoriasis differed between men and women worldwide. ${ }^{42}$ In this study, plaque psoriasis is the most frequent form in the major regions of Saudi Arabia with a prevalent rate reaching $87 \%$ except in the southern regions where guttate psoriasis is more predominant. ${ }^{23,24}$ Guttate psoriasis is the second most common form of psoriasis in the majority of Saudi research (Table 2). The prevalence of guttate psoriasis vary widely in 
Table 2 Type of Psoriasis Prevalent and Common Sites Involved in KSA

\begin{tabular}{|c|c|c|c|c|c|c|c|c|c|c|c|c|c|c|}
\hline Reference & $\begin{array}{l}\text { Plaque } \\
\text { Psoriasis }\end{array}$ & $\begin{array}{l}\text { Guttate } \\
\text { Psoriasis }\end{array}$ & Mixed & $\begin{array}{l}\text { Pustular } \\
\text { Psoriasis }\end{array}$ & $\begin{array}{l}\text { Inverse } \\
\text { Psoriasis }\end{array}$ & $\begin{array}{l}\text { Erythro- } \\
\text { Psoriasis }\end{array}$ & Follicular & Congenital & $\begin{array}{l}\text { Lower } \\
\text { Limb }\end{array}$ & Scalp & Elbow & $\begin{array}{l}\text { Palmo- } \\
\text { Plantar }\end{array}$ & Genital & Other \\
\hline Fatani et al $2002^{21}$ & $87.1 \%$ & $1.9 \%$ & & $3 \%$ & & $4.2 \%$ & $0.4 \%$ & & $44.9 \%$ & $41.8 \%$ & - & $12.6 \%$ & & $26.6 \%$ \\
\hline Bhutto et al $201 \mathrm{I}^{22}$ & $33.3 \%$ & $22.2 \%$ & $16.7 \%$ & & & & & & $11 \%$ & $2.8 \%$ & $2.85 \%$ & - & & Rest \\
\hline Alsuwaidan $20 \mathrm{II}^{33}$ & $66 \%$ & $22.2 \%$ & $11.1 \%$ & & & & & $1 \%$ & $16.6 \%$ & $2.77 \%$ & - & $11.1 \%$ & - & Rest \\
\hline Alhumidi $2013^{23}$ & $69 \%$ & $8 \%$ & & $5 \%$ & & $2 \%$ & & & $27 \%$ & $8 \%$ & & $20 \%$ & $9 \%$ & Rest \\
\hline Shajeri et al $2014^{24}$ & $52 \%$ & $64 \%$ & & & $4 \%$ & & & & & & & & & \\
\hline Hassan et al $2017^{25}$ & $24 \%$ & $2 \%$ & & $5 \%$ & & & & & & & & & & \\
\hline Alabdullah et al $2017^{41}$ & & & & & & & & & $67.9 \%$ & $75.0 \%$ & $56.0 \%$ & $41.7 \%$ & - & Rest \\
\hline
\end{tabular}


our study and others who cite the prevalence of less than $30 \%$ among patients with psoriasis. ${ }^{45}$ Our findings are consistent with other studies that have quoted a high incidence of plaque psoriasis. ${ }^{44,45}$

Other phenotypes of psoriasis are infrequently reported. Inverse psoriasis and pustular psoriasis were found to be rare in the current research, accounting for only $5 \%$ of patients with psoriasis. Congenital psoriasis and follicular psoriasis were revealed to be the least frequent forms of psoriasis among the Saudi population in this study. These findings are in line with international literatures. ${ }^{1,7}$ Finally, the reviewed data showed that Psoriasis is unequally distributed in the KSA and there is still limited information about the epidemiology of the disease. Therefore, further studies that include a comprehensive screening for the type of psoriasis and a reliable stratification of clinical presentation and possibly genetic study will provide robust information that can aid in the development of specialized health initiatives and treatment regimens.

\section{Conclusion}

Psoriasis is quite common in Saudi Arabia and it was more prevalent in the northern region. Plaque-type psoriasis is the most frequent cutaneous manifestation, followed by guttate type. The data's heterogeneity makes comparison difficult. Therefore, the consistency in reporting the clinical manifestation of psoriasis and possibly establishing a regional registry for the disease is highly sought after. It is also critical to have a better understanding of the epidemiology of psoriasis so that resources may be targeted to enhance the disease's prevention and minimize its, morbidity, disability, and death.

\section{Strength and Limitation of the Study}

The comprehensive search of all available literature on cutaneous symptoms of psoriasis from KSA is one of this review's strengths. The research's variability in terms of age, gender, region, and environmental triggers make the comparison difficult. Furthermore, the data of some studies were collected retrospectively which makes the conclusion up for debate.

\section{What This Study Adds}

This review aims to shed a light on the occurrence of psoriasis in Saudi Arabia. A better knowledge of cutaneous manifestations can aid in forecasting future disease burden and resource allocation to minimize the illness's morbidity, disability, and death.

\section{Disclosure}

The authors report no conflicts of interest in this work.

\section{References}

1. Langley RG, Krueger GG, Griffiths CE. Psoriasis: epidemiology, clinical features, and quality of life. Ann Rheum Dis. 2005;64(2):ii18-ii23. doi:10.1136/ard.2004.033217

2. Gudjonsson JE, Elder JT. Psoriasis: epidemiology. Clin Dermatol. 2007;25(6):535-546. doi:10.1016/j.clindermatol.2007.08.007

3. Christophers E. Psoriasis epidemiology and clinical spectrum. Clin Exp Dermatol. 2001;26:314-320. doi:10.1046/j.1365-2230.2001.00832.x

4. World Health Organization. Global report on psoriasis. Available from: https://apps.who.int/iris/handle/10665/204417. Accessed May 18, 2020.

5. Michalek IM, Loring B, John SM. A systematic review of worldwide epidemiology of psoriasis. J Eur Acad Dermatol. 2017;31(2):205-212.

6. Farber EM, Nall L. Epidemiology natural history and genetics. In: Roenigk HH Jr., Maibach HI, editors. Psoriasis. New York: Dekker; 1998:107-115.

7. Enamandram M, Kimball A. Psoriasis epidemiology: the interplay of genes and the environment. J Invest Dermatol. 2013;133:287-289. doi: $10.1038 /$ jid.2012.434

8. Griffiths CE, Christophers E, Barker JN, et al. A classification of psoriasis vulgaris according to phenotype. Br J Dermatol. 2007;156:258-262. doi:10.1111/j.1365-2133.2006.07675.x

9. Mehlis SL, Gordon KB. The immunology of psoriasis and biological immunotherapy. J Am Acad Dermatol. 2003;49(2):S44-S50. doi:10.1016/ S0190-9622(03)01134-4

10. Agarwal PK. Pattern of skin diseases in Al-Jouf region. Ann Saudi Med. 1997;17(1):112-114. doi:10.5144/0256-4947.1997.112

11. Al Shammrie F, Al Shammrie A. Pattern of skin disease in Hail region of Saudi ArabiaJ. Dermatol Dermatol Surg. 2017;21(2):62-65. doi:10.1016/ j.jdds.2017.04.001

12. Albasri AM, Ansari IA. The histopathological pattern of benign and non-neoplastic skin diseases at King Fahad hospital, Madinah, Saudi Arabia. Saudi Med J. 2019;40(6):548. doi:10.15537/smj.2019.6.24205

13. Shelleh HH, Al-Hatiti HS. Pattern of skin diseases in a hospital in southwestern Saudi Arabia. Saudi Med J. 2004;25(4):507-510. 
14. Al Akloby O. Pattern of skin diseases in the Eastern Province (EP) of Saudi Arabia. Saudi Med J. 2005;26(10):1607-1610.

15. Al-Saeed WY, Al-Dawood KM, Bukhari IA, Bahnassy AA. Prevalence and pattern of skin disorders among female schoolchildren in Eastern Saudi Arabia. Saudi Med J. 2006;27(2):227-234.

16. Al-Hoqail IA. Epidemiological spectrum of common dermatological conditions of patients attending dermatological consultations in Al-Majmaah region (Kingdom of Saudi Arabia). J Taibah Univ Medical Sci. 2013;8(1):31-37.

17. Alshamrani HM, Alsolami MA, Alshehri AM, et al. Pattern of skin diseases in a university hospital in Jeddah, Saudi Arabia: age and sex distribution. Annals Saudi Med. 2019;39(1):22-28. doi:10.5144/0256-4947.2019.22

18. Griffiths CE, Barker JN. Pathogenesis and clinical features of psoriasis. Lancet. 2007;370(9583):263-271. doi:10.1016/S0140-6736(07)61128-3

19. Meier M, Sheth PB. Clinical spectrum and severity of psoriasis. Curr Probl Dermatol. 2009;38:1-20.

20. Parthasaradhi A, Al Gufai AF. The pattern of skin diseases in Hail region, Saudi Arabia. Ann Saudi Med. 1998;18(6):558-561. doi:10.5144/02564947.1998.558

21. Fatani MI, Abdulghani MH, Al-Afif KA. Psoriasis in the eastern Saudi Arabia. Saudi Med J. 2002;23(2):213-217.

22. Bhutto AM, Al-Ajlan AM, Al-Suwaidan SN. Characteristics and pattern of childhood psoriasis in Saudi Arabia. J Pak Assoc Dermatol. 2011;21 (3):159-164.

23. Alhumidi AA. Retrospective 10 years review of 100 patients with psoriasis in the Kingdom of Saudi Arabia (KSA). Am J Res Commun. 2013;8:114-120.

24. Shajeri MA, Al-Fahaad H. Psoriasis in children: a study from the southern part of Saudi Arabia. Gulf J Dermatol Venereol. 2014;21(1):34-37.

25. Hassan SA, Abdullah OA, Rana OA, Rana OH. Proportions of major comorbid medical conditions among psoriasis patients in a tertiary hospital, Riyadh. J Health Special. 2017;5(3):176. doi:10.4103/jhs.JHS_136_16

26. Almohideb M. Epidemiological patterns of skin disease in Saudi Arabia: a systematic review and meta-analysis. Dermatol Res Pract. 2020;2020:5281957. doi:10.1155/2020/5281957

27. Alajmi RS, Alamoudi SM, Alabbasi AA, Alwagdani A, Alraddadi AA, Alamri A. Patterns of comorbidities in psoriasis patients: a cross-sectional study. Cureus. 2021;13(5):e14907. doi:10.7759/cureus.14907

28. Bahamdan KA, Egere JU, Khare AK, Tallab T, Ibrahim K, Mourad M. The pattern of skin diseases in Asir region, Saudi Arabia: a 12-month prospective study in a referral hospital. Ann Saudi Med. 1995;15(5):455-457. doi:10.5144/0256-4947.1995.455

29. Raddadi AA, Abdullah SA, Damanhouri ZB. Pattern of skin diseases at King Khalid National Guard Hospital: a 12-month prospective study. Ann Saudi Med. 1999;19(5):453-454. doi:10.5144/0256-4947.1999.453

30. Al-Maghrabi JA, Al-Ghamdi AS, Elhakeem HA. Pattern of skin cancer in Southwestern Saudi Arabia. Saudi Med J. 2004;25(6):776-779.

31. Al-Zoman AY, Al-Asmari FAK. Pattern of skin diseases at Riyadh Military hospital. Egypt Dermatol Online J. 2008;4(2):4.

32. Amin TT, Ali A, Kaliyadan F. Skin disorders among male primary school children in Al Hassa, Saudi Arabia: prevalence and socio-demographic correlates-a comparison of urban and rural populations. Rural Remote Health. 2011;11(1):1517.

33. Alsuwaidan SN. Childhood psoriasis: analytic retrospective study in Saudi patients. J Saudi Soc Dermatol Dermatologic Surg. 2011;15(2):57-61. doi:10.1016/j.jssdds.2011.04.005

34. Al Fahaad HA. Clinico-epidemiological profile of vitiligo patients in Najran Region, Saudi Arabia. J Dermatol Dermatologic Surg. 2015;19:31-35. doi:10.1016/j.jdds.2014.05.001

35. Fatani MI, Habibullah TH, Alfif KA, Ibrahim AI, Althebyani B. Impact of psoriasis on quality of life at Hera General Hospital in Makkah, Saudi Arabia. Clinic Med Diagnost. 2016;6(1):7-12.

36. Albahlool AM, Drain BY, Alqurashi GG, et al. Common dermatological diseases in Saudi Arabia: a literature review. Egypt J Hosp Med. 2017;67 (1):475-481. doi:10.12816/0036664

37. Rahamathulla MP. Prevalence of skin disorders and associated socio-economic factors among primary school children in the Eastern region of Saudi Arabia. J Pak Med Assoc. 2019;69(8):1175-1180.

38. Albarraq AA, Alqahtani SS, Ahmad S, Banji D. Prevalence and pharmacotherapeutic management of pediatric psoriasis-a descriptive review. Indian J Pharm Educ Res. 2019;53(4):569-576. doi:10.5530/ijper.53.4.118

39. Elnady B, El Shaarawy NK, Dawoud NM, et al. Subclinical synovitis and enthesitis in psoriasis patients and controls by ultrasonography in Saudi Arabia; incidence of psoriatic arthritis during two years. Clin Rheumatol. 2019;38(6):1627-1635.

40. Almutairi S, Alotaibi A, Almohideb MA. Perception and assessment of psoriasis in the general population of Riyadh, Saudi Arabia. Saudi J Health Sci. 2020;9:102-108. doi:10.4103/sjhs.sjhs_180_19

41. Alabdullah AA, Alhaddad MJ, Alabdullah YA, et al. Impact of psoriasis on quality of life in eastern province, Saudi Arabia. Int $J$ Adv Res. 2017;5:456-462. doi:10.21474/IJAR01/5979

42. Parisi R, Iskandar IY, Kontopantelis E, Augustin M, Griffiths CE, Ashcroft DM. National, regional, and worldwide epidemiology of psoriasis: systematic analysis and modelling study. BMJ. 2020;369. doi:10.1136/bmj.m1590

43. World Health Organization. Global report on psoriasis. World Health Organization; 2016. Avialable from: https://apps.who.int/iris/handle/10665/ 204417. Accessed February 18, 2022.

44. AlQassimi S, AlBrashdi S, Galadari H, Hashim MJ. Global burden of psoriasis-comparison of regional and global epidemiology, 1990 to 2017. Int J Dermatol. 2020;59(5):566-571. doi:10.1111/ijd.14864

45. Parisi R, Symmons DP, Griffiths CE, Ashcroft DM. Global epidemiology of psoriasis: a systematic review of incidence and prevalence. $J$ Invest Dermatol. 2013;133(2):377-385. doi:10.1038/jid.2012.339 


\section{Publish your work in this journal}

Clinical, Cosmetic and Investigational Dermatology is an international, peer-reviewed, open access, online journal that focuses on the latest clinical and experimental research in all aspects of skin disease and cosmetic interventions. This journal is indexed on CAS. The manuscript management system is completely online and includes a very quick and fair peer-review system, which is all easy to use. Visit http://www. dovepress.com/testimonials.php to read real quotes from published authors.

Submit your manuscript here: https://www.dovepress.com/clinical-cosmetic-and-investigational-dermatology-journal 